MICHELLE J. WHITE

University of California, San Diego

\title{
Sovereigns in Distress: Do They Need Bankruptcy?
}

SHOULD THERE BE a sovereign bankruptcy procedure for countries in financial distress? This paper explores the use of U.S. bankruptcy law as a model for a sovereign bankruptcy procedure and asks whether adoption of such a procedure would lead to a more orderly process of sovereign debt restructuring. It assumes that a quick and orderly debt restructuring process is more efficient than a prolonged and disorderly one, because a lengthy process of debt restructuring takes a high toll on debtor countries' economies as well as harming creditors in general. I concentrate on three goals for a sovereign bankruptcy procedure: preventing individual creditors or groups of creditors from suing the debtor for repayment, preventing groups of creditors from strategically delaying negotiations or acting as holdouts, and increasing the likelihood that private creditors will provide new loans to sovereign debtors in financial distress, thus reducing the pressure on the International Monetary Fund (IMF) to fund bailouts. I conclude that nonbankruptcy alternatives are less likely to accomplish these goals than a sovereign bankruptcy procedure.

\section{U.S. Bankruptcy Law and Important Trade-Offs in Bankruptcy}

Three sections of the U.S. Bankruptcy Code are of possible relevance for a future international bankruptcy procedure: Chapter 7 (bankruptcy

I am grateful to Edwin Truman and Marcus Miller for helpful comments and discussion. 
liquidation), Chapter 11 (corporate reorganization), and Chapter 9 (municipal bankruptcy).

\section{Chapter 7}

Chapter 7 is the U.S. bankruptcy liquidation procedure for both corporations and individuals. When a corporation files under Chapter 7, its operations are shut down and the corporation ceases to exist. Its assets are liquidated and the proceeds distributed among creditors according to the absolute priority rule (APR, described below). When an individual files under Chapter 7, his or her assets are divided into exempt and nonexempt categories. Nonexempt assets are liquidated and the proceeds distributed among creditors according to the APR. The individual's postbankruptcy earnings are completely exempt from the obligation to repay prebankruptcy debt. For both individuals and corporations, any debt not repaid by the liquidation procedure is discharged. ${ }^{1}$

Under the APR the administrative expenses of bankruptcy are paid first, unsecured creditors second, and anything left goes to equity holders. $^{2}$ Each class of creditors must be paid in full before lower-ranking classes receive anything. Unsecured creditors' claims may be divided into subclasses if their contracts with the firm contain subordination agreements, but otherwise all of their claims are treated equally. Claims due in the future (such as long-term bonds) are accelerated to the present. Thus bankruptcy liquidation is a collective procedure aimed at resolving all claims against the debtor.

An important advantage of a bankruptcy procedure, whether it involves liquidation or reorganization, is that it reduces creditors' incentives to engage in a race to seize the debtor's assets. As in a bank run, when individual creditors perceive that the debtor's assets are insufficient to repay all of its debts, they have an incentive to race to be repaid before the debtor's funds run out. Such a grab race is destructive, because it results in particular assets of the debtor being liquidated in order to satisfy the winners' claims, even though the debtor's assets may be more valuable if

1. Bankruptcy thus limits the obligation of individuals to repay personal debt or debt of their unincorporated businesses in the same way that limited liability limits the obligation of corporate shareholders to repay corporate debt.

2. Secured creditors are outside the priority ordering, and in liquidation they reclaim the assets securing their loans. Priority claims, including claims for unpaid taxes and wages, are paid after administrative expenses but before unsecured claims. 
they remain together. For example, a firm may be unable to continue producing goods if a creditor seizes its main computer, even though it still has all of its other equipment. In the sovereign debt context, a debtor country's manufacturing sector may suffer because it cannot import fuel if a creditor attaches the country's external bank account. The point of the bankruptcy procedure is to reduce creditors' incentive to race for payment by resolving all of the firm's debts at once. If creditors know that winning a grab race will cause the firm to file for bankruptcy, they will have little incentive to enter the race at all, because doing so will not increase their reward unless they win early enough to collect without tipping the debtor into bankruptcy. ${ }^{3}$

The race by creditors to be first to collect from a failing firm is an example of a prisoners' dilemma. To illustrate, suppose a firm has two creditors of equal priority: creditor 1 , who is owed 5 , and creditor 2 , who is owed 4. Suppose further that, if one or both creditors race to collect first, the firm's assets will be liquidated piecemeal and will be worth 5 in total. As figure 1 shows, if creditor 1 races to collect but creditor 2 does not, creditor 1 gets full repayment of 5 and creditor 2 gets zero, whereas if creditor 2 races to collect but creditor 1 does not, creditor 2 gets full repayment of 4 and creditor 1 gets 1 . Now suppose that if both creditors race to be first, the expected outcome is that creditor 1 gets 3 and creditor 2 gets 2, and that if both creditors agree not to race against each other, the firm's assets will be worth 7 rather than 5. Under these assumptions the assets are worth more when creditors do not race; in practice this could be because they are sold all at once rather than piecemeal or because they are sold when they have maximum value. If neither creditor races, then, because both have equal priority, each is paid seven-ninths of its claims: creditor 1 receives 3.9 and creditor 2 receives 3.1. Although the creditors together are better off in the no-race outcome, each is worse off than if it wins the grab race, and thus the only equilibrium of the game is that both creditors race.

In this context we can interpret bankruptcy liquidation as a mandatory procedure that imposes the outcome that neither creditor races (the "no-race/no-race" outcome), since both creditors' attempts to collect are stayed by the firm's bankruptcy filing. The resulting increase in the value

3. Even this may not work, because the bankruptcy trustee can void payments made to creditors within a fixed time interval before the firm's bankruptcy filing; such payments are known as "preferential transfers" (Jackson, 1986). 
Figure 1. Payoff Matrix for Creditors Choosing Whether to Race to Collect from a Bankrupt Debtor ${ }^{a}$

\begin{tabular}{c|c|c|c|}
\multicolumn{1}{c}{} & \multicolumn{2}{c}{ Creditor 1 } \\
\cline { 3 - 4 } Creditor 2 & \multicolumn{2}{c}{$\begin{array}{c}\text { Doesn't } \\
\text { race }\end{array}$} & \multicolumn{1}{c}{ Races } \\
\cline { 3 - 4 } & $\begin{array}{c}\text { Doesn't } \\
\text { race }\end{array}$ & $3.9,3.1$ & $1.0,4.0$ \\
\cline { 3 - 4 } & Races & $5.0,0.0$ & $3.0,2.0$ \\
\cline { 3 - 4 } & &
\end{tabular}

Source: Author's model as described in the text.

a. The first number in each cell is the payoff to creditor 1 (who is owed 5) and the second is that for creditor 2 (who is owed 4).

of the firm's assets is the justification for imposing bankruptcy liquidation as a mandatory collective procedure. ${ }^{4}$

Now consider the analogy between creditors in a grab race and depositors in a bank run. Both actions result from individuals' incentive to protect their own claims when the debtor's total assets are (or are perceived to be) less than its total liabilities. In bankruptcy, the APR does not promise full repayment of creditors' claims, but only to divide the assets according to a predetermined procedure. However, in a bank run, the usual solution is for the deposit insurer to reimburse depositors for the full amount of their deposits. Such a bailout would substitute payouts of 5 to creditor 1 and 4 to creditor 2 for the payouts of 3.9 and 3.1 in the upper left box of figure 1. With these payouts, the no-race/no-race outcome is a possible equilibrium of the game, since creditor 1 is indifferent between racing and not racing when creditor 2 chooses not to race, and creditor 2 is indifferent between racing and not racing when creditor 1 chooses not to race. Thus the no-race/no-race outcome and the race/race outcome are both possible. Because no-race/no-race is a possible equilibrium of the game, bailouts are a possible solution to the problem of bank runs or creditor grab races. However, the analogy of bankruptcy and bank runs suggests that the problem could instead be solved by substituting bankruptcy for a bailout.

4. In the United Kingdom, private creditors liquidate failing firms' assets individually rather than collectively, and failing firms are thought to shut down prematurely as a result (see Webb, 1991, for a discussion). 
In the sovereign debt context, an important issue is how to improve debtor countries' access to new loans, even when debtors are likely to default or have already defaulted on their sovereign debt. The priority rule in bankruptcy, that is, the order in which creditors are paid, is an important determinant of the availability of new loans to firms in financial distress, because later loans have external effects on earlier loans, and these externalities affect creditors" willingness to lend. Consider the "me-first" rule, which specifies that, in a bankruptcy, loans are repaid in full in chronological order: the first to lend is first in line for repayment. Under this rule, later loans have no direct external effect on the value of earlier loans, because earlier loans are repaid in full before later loans receive anything. ${ }^{5}$ As a result, late lending is unattractive to creditors because their claims are unlikely to be repaid, but early lending is attractive. Now consider the "last lender first" rule, which specifies that loans are repaid in reverse chronological order. Under this rule, late loans reduce the value of early loans, because late loans must be fully repaid before early loans receive anything. Relative to the "me-first" rule, late lending is attractive, but early lending is not. Finally, the "pari passu" or equal priority rule is in between. Under this rule, late loans reduce the value of early loans, but not by as much as under the "last lender first" rule. ${ }^{6}$ U.S. firms in financial distress often obtain late loans by giving late creditors secured interests in particular assets, which is equivalent to using the "last lender first" rule. In contrast, countries in financial distress find it much more difficult to obtain late loans, both because all loans have equal priority and because sovereign debtors cannot provide security to late lenders.

Liquidation is potentially an important component of a sovereign bankruptcy procedure. Distressed countries would not disappear from the world map if they liquidated in bankruptcy. Rather, a liquidation procedure for countries would be similar to the liquidation procedure for individuals in the United States. The country's assets held abroad would be divided into exempt and nonexempt categories, based on whether the asset is covered by sovereign immunity. In the United States and the United Kingdom, sovereigns' diplomatic assets are covered by sovereign

5. However, if late loans allow the firm to avoid bankruptcy, and it then engages in risky investments, the value of early loans may fall.

6. See Bulow and Shoven (1978) and White (1989) for models of the bankruptcy decision that demonstrate the effects of priority rules and show that no priority rule always gives managers incentives to make efficient bankruptcy decisions. 
immunity, but their commercial assets are not. Assets not covered by sovereign immunity would be liquidated and the proceeds used to repay the country's creditors according to the APR. Any debt not repaid from the sale of nonexempt assets would be discharged. All of the country's assets held at home would be covered by the country's own law and would presumably be exempt. The country's postbankruptcy "earnings" (that is, tax revenue) would also be exempt. I argue below that a liquidation procedure along the lines of Chapter 7 would be a useful component of a sovereign bankruptcy procedure, as an alternative to be used if negotiations over a restructuring plan break down.

\section{Chapter 11}

Chapter 11 is the U.S. reorganization procedure for corporations, and most sovereign bankruptcy proposals are more or less based on it. ${ }^{7}$ It allows corporations to continue operating and to repay part or all of their creditors' claims from future earnings, rather than shut down and repay creditors from the proceeds of liquidating their assets. Managers have the right to choose between filing under Chapter 7 and filing under Chapter 11. Under Chapter 11, existing managers of corporations usually remain in control as "debtors in possession." The bankruptcy judge loosely oversees the manager, because the judge must approve any major changes such as new loans or sales of assets.

Several provisions of Chapter 11 are intended to help the corporation survive by improving its short-term financial situation. First, there is an automatic stay on prebankruptcy litigation in which the firm is a defendant. Chapter 11 also prevents creditors from filing new lawsuits against the firm after the bankruptcy filing. Litigation against the firm is often transferred to the bankruptcy court and decided by the bankruptcy judge as part of the bankruptcy proceedings. Second, firms in Chapter 11 cease paying interest on unsecured debt until the reorganization plan is adopted and then make payments according to the terms of the plan. This reduces both the immediate and the longer-term financial demands on firms in bankruptcy. Third, firms can usually obtain new loans—-known as debtorin-possession financing-because postpetition loans take priority over all

7. See White (1998) for a discussion of Chapter 11. For a comparison of reorganization procedures in the United States with those in various European countries, see White (1996b). 
prebankruptcy claims as an administrative expense of bankruptcy. This makes lending to firms in Chapter 11 very attractive. ${ }^{8}$

Managers have the exclusive right to propose a reorganization plan for four months after the firm files for bankruptcy, and often the bankruptcy judge extends the exclusivity period. The reorganization plan specifies how much each class of creditors will receive in cash and new claims on the reorganized firm. Assuming that the firm's assets are worth more in reorganization than in liquidation, Chapter 11 provides a framework within which creditors and managers can bargain over the distribution of the extra value. If and when the bankruptcy judge ends the managers' exclusivity period, creditors may propose their own reorganization plan. But often managers succeed in persuading the judge to extend the exclusivity period long enough that creditors never have an opportunity to offer their own plans.

Reorganization plans are voted on, and the requirement for acceptance is that each class of creditors must approve the plan by a margin of at least two-thirds in amount and a simple majority in number of claims. Twothirds of equity must also vote in favor of the plan. Thus the Chapter 11 voting procedure incorporates a mechanism for compelling dissenting creditors to accept a reorganization plan as long as they constitute less than a specified minority of each class.

An important aspect of bankruptcy reorganization is the alternative procedure that is followed when no reorganization plan is adopted by vote. The bankruptcy judge makes this decision. The judge may order the firm to be liquidated under Chapter 7. Or the judge may adopt the reorganization plan even though it failed the voting test, using a procedure called "cramdown." The requirements for cramdown are that at least one class of impaired creditors meet the voting margin for adoption of the plan, that each class of creditors receive at least what the class would have received in liquidation, and that any class of unsecured creditors that rejected the plan be repaid in full or else lower-ranking classes of creditors cannot receive anything. Note that if all creditors had equal priority (as they would in sovereign bankruptcies), the latter test requires only that all classes of creditors receive at least what they would get in liquidation.

8. An additional feature of Chapter 11 is that secured creditors cannot remove assets on which they have liens while the firm is in Chapter 11 (although the value of their claims must be protected). 
As will be discussed below, cramdown is an extremely important part of bankruptcy, because it allows a reorganization plan to be adopted despite the opposition of entire classes of creditors. ${ }^{9}$

Chapter 11 is highly favorable to managers and equity holders of financially distressed firms, because managers remain in control while their firms go through the procedure, and equity remains intact as long as the reorganization plan is adopted by vote. There is an important trade-off in making bankruptcy reorganization favorable to managers and equity. One side of the trade-off is that managers otherwise might engage in activities that are destructive to the firm, because they have strong incentives to avoid bankruptcy. For example, managers might seek to gain from taking the firm's cash to Las Vegas, where a high-stakes gamble would save the firm from bankruptcy if it wins and cost managers little if it loses, since they would lose their jobs anyway if the firm went bankrupt. ${ }^{10}$ Alternatively, managers might loot the firm's assets before filing for bankruptcy or delay filing until all of the firm's assets have been used up. Thus a gain from having a bankruptcy procedure that treats managers favorably is that their firms enter bankruptcy in better financial shape and are therefore more likely to be saved.

But the other side of the trade-off is that, when the bankruptcy procedure is favorable to managers, they have an incentive to file too often. The models illustrating this point assume that there are two types of firms, solvent and insolvent, and creditors cannot distinguish between them at the time they file for bankruptcy. All managers of insolvent firms file to reorganize under Chapter 11, whereas managers of solvent firms choose whether to file under Chapter 11 or to avoid bankruptcy and repay their creditors in full. All managers of firms in Chapter 11 offer reorganization plans that reduce creditors' claims by the same proportion, and creditors must decide whether to accept or reject these plans without knowing to which category a firm belongs. If the proportion of insolvent firms among those in bankruptcy is large enough, creditors' best strategy is to accept all reorganization plans. The reason is that creditors lose when they reject

9. Note that the term "cramdown" is sometimes used in the sovereign debt context to refer to a collective action clause, discussed below. Here I use it in the bankruptcy sense to indicate a mechanism for overriding entire classes of creditors. Adoption of a reorganization plan using cramdown takes longer and involves higher transactions costs than adoption by the voting procedure.

10. See Stiglitz (1972). 
a plan and the firm turns out to be insolvent. Thus, in equilibrium, managers may file under Chapter 11 and reorganize even though their firms are solvent and could afford to repay creditors in full. Similar models suggest that managers may also exert too little effort in managing their firms and may choose investments that entrench themselves. ${ }^{11}$

Both sides of the trade-off also apply to sovereign default. During the East Asian crisis, public officials in several countries went to extraordinary lengths to defend the value of their currencies and avoid running out of foreign exchange, in the process causing domestic businesses to fail and their economies to go into deep recession. ${ }^{12}$ Thus there may have been too few defaults. On the other hand, the theoretical literature on sovereign default emphasizes public officials' incentives to borrow and then default on their foreign debt, because neither the penalties of exclusion from credit markets nor those from loss of reputation are severe enough to make it worthwhile for debtor countries always to repay. The prediction that sovereign debtors default too often applies regardless of whether the debtor countries use the borrowed funds for efficient or for wasteful economic policies. ${ }^{13}$

\section{Chapter 9}

Chapter 9, the bankruptcy procedure for U.S. municipalities, has been discussed as a possible model for a sovereign bankruptcy procedure. ${ }^{14}$ Chapter 9 is based on Chapter 11 but differs in a number of respects. First, a municipality must obtain permission from its state to file for bankruptcy, and the filing must be voluntary on the part of municipal officials.

11. See Hart and Moore (1989), Berglof and von Thadden (1994), and White (1998).

12. See Blustein $(2001$, p. 87) for a discussion of Indonesia's response to its financial crisis.

13. See Eaton and Gersovitz (1981), Eaton and Fernandez (1995), and Bulow and Rogoff (1989) for models.

14. Several aspects of Chapter 9 reflect how the U.S. Constitution treats the relationship between states and the federal government. One is that Chapter 9 does not apply to U.S. states or counties, because these are considered sovereign entities, and the U.S. Constitution prevents the federal government from interfering in the internal governance of sovereign states or their political subdivisions. Chapter 9 thus applies only to cities, townships, and special entities such as school districts or publicly owned utilities, which are not sovereign because they are creations of the states. Also, states are not allowed to adopt their own bankruptcy laws, because the Constitution does not allow states to adopt legislation that interferes with contracts, and bankruptcy interferes with contracts between municipalities and their creditors. See McConnell and Picker (1993). 
Second, the municipality must be insolvent on a cash flow basis, unable to pay debts as they come due, in order to file for bankruptcy. This is a more stringent standard than that applied to firms filing under Chapter 11. Before filing, municipalities must attempt to work out a restructuring plan, although they may file for bankruptcy if the attempt fails. Third, public officials - unlike managers of corporations - can never be replaced in bankruptcy, on the grounds that doing so would interfere with sovereignty. Fourth, public officials always have the exclusive right to offer a restructuring or reorganization plan. Creditors have the right to form a committee to negotiate with the public officials, but they cannot propose their own plan.

Restructuring plans are adopted by a voting procedure similar to that in Chapter 11 and with the same voting requirements for creditors. If a plan is not adopted by vote, however, the alternative procedure is ambiguous, because municipalities cannot be liquidated under Chapter 7. Bankruptcy judges are allowed to use cramdown to adopt a restructuring plan, but there is no analogue in Chapter 9 to the various tests that must be satisfied in order to use cramdown under Chapter 11. Another possible alternative procedure is for the bankruptcy judge to formulate his or her own restructuring plan based on the municipality's ability to repay. The reorganization plan would then require the municipality to raise taxes, sell assets, cut expenditure, reject collective bargaining agreements, or do whatever else is necessary to pay for the plan. This has never happened under Chapter 9, but it could in theory. ${ }^{15}$ The lack of a clear alternative procedure to be followed if negotiations over a restructuring plan break down is also a problem with proposals for sovereign bankruptcy procedures.

Chapter 9 provides little guidance for a sovereign bankruptcy procedure because it has been used only rarely. Only three general-purpose municipalities used the procedure between 1972 and 1984, and all were very small towns. ${ }^{16}$ The largest bankruptcy filings so far under Chapter 9 have been those of Bridgeport, Connecticut, and Orange County, California. Although Bridgeport was running a large budget deficit and had the highest property tax rate in the state at the time it filed for bankruptcy, the

15. See McConnell and Picker (1993, p. 465) for discussion of precedents in which creditors appealed a restructuring plan and the appeals court considered the debtor's ability to repay creditors' claims by raising taxes or making other adjustments.

16. However, several hundred special-purpose governmental entities such as drainage districts have used Chapter 9. See McConnell and Picker (1993). 
bankruptcy court rejected its filing on the grounds that it had not exhausted its borrowing power and was therefore not insolvent. Bridgeport's bankruptcy filing was also opposed by the state of Connecticut, which had already appointed its own financial review board to deal with Bridgeport's financial distress. ${ }^{17}$ States have a general interest in preventing their municipalities from filing for bankruptcy, because allowing one municipality to file signals that the state will not bail out other municipalities if they get into financial distress, and this in turn raises municipal borrowing costs within the state. However, when Orange County filed for bankruptcy in 1994 because of $\$ 1.64$ billion in losses on investments made by the county treasurer, California did not attempt to stop it.

The Orange County bankruptcy experience provides some support for a sovereign bankruptcy procedure in the sense that the reorganization process was both orderly and quick. Within one and a half years after the county filed for bankruptcy, a reorganization plan had been adopted that called for full repayment of creditors' claims (excluding lost interest). This probably would not have been possible without the automatic stay on litigation and the financial relief provided by the suspension of payments to creditors. ${ }^{18}$

Thus Chapter 9 provides a precedent for a bankruptcy procedure for governments in financial distress. However, it provides little guidance concerning how a sovereign bankruptcy procedure would work in practice.

\section{Differences between Sovereign Default and Corporate Bankruptcy}

How does sovereign default differ from corporate bankruptcy, and why is the former so costly? First, default by a country often involves a

17. Bridgeport's conflict with the state of Connecticut is reminiscent of conflicts between the IMF and debtor countries. The state's financial review board was about to force the city to raise its property taxes by 18 percent when the city filed for bankruptcy. Bridgeport's officials wanted instead to resolve the city's financial problems by breaking "burdensome" union contracts. See George Judson, "U.S. Judge Blocks Bridgeport from Bankruptcy Court," New York Times, August 2, 1991.

18. Orange County raised funds for the plan by laying off workers, selling some assets, cutting expenditure, and issuing new bonds. It attempted to raise its local sales tax, but voters rejected the proposed increase. See "Orange County Adopts Plan to Get out of Bankruptcy," New York Times, December 22, 1995, p. D2. 
currency crisis in which both international and domestic investors become fearful about the country's prospects and race to sell their financial assets and convert local currency into dollars. This quickly drains the country's stock of hard-currency reserves. To stem the outflow and reduce the chance of running out of reserves, countries often raise domestic interest rates to very high levels. The high interest rates in turn do substantial damage to the economy. Firms that have borrowed abroad in dollars default on their loans, because the cost of purchasing dollars with which to repay those loans has risen sharply. Firms that have borrowed from local banks in the local currency are likely to default as well, because they cannot afford to pay the high interest rates. Local banks become insolvent and cease lending. Firms go bankrupt, workers are laid off, households cut their consumption, and the country's economy may go into a severe recession. Further, events in one country often make investors fearful of contagion, and they begin to sell financial assets in neighboring countries, causing the problem to spread. Preventing a financial crisis from becoming an economic crisis and spreading to other countries is the major reason why the IMF often intervenes in financial crises with a bailout. More generally, this scenario suggests that there is an international public interest in preventing financial crises or limiting their severity and spread. But if politicians and investors anticipate that the IMF will come to the rescue of countries facing financial crises, their incentive to prevent such crises by following good economic policies or restricting their international borrowing is weakened. ${ }^{19}$

Jeffrey Sachs argues that when the restructuring process is prolonged and debtor countries cannot borrow from abroad, their investment levels and economic growth rates fall. He also argues that default has a high political cost, in that elected governments may fall because of voters' negative reaction to the recession or to the IMF's demands that the government sharply cut expenditure or increase taxes. ${ }^{20}$

19. Preventing contagion is sometimes an issue when large corporations file for bankruptcy as well. The federal government bailed out the Chrysler Corporation in the 1970s and arranged for commercial banks to bail out Long-Term Capital Management in the 1990s. Executives of Enron attempted, although unsuccessfully, to get government help before they filed for bankruptcy. See Blustein (2001, pp. 305-31) for a discussion of Long-Term Capital Management, and Richard W. Stevenson, "Enron Sought Aid of Treasury Dept. to Get Bank Loans," New York Times, January 12, 2002, p. A1.

20. Sachs (1989) argues that, when a country defaults, its growth rate falls because it cannot borrow more until a restructuring plan is agreed on, and this starves the economy of 
Second, whereas all of the assets of a bankrupt corporation are available to repay creditors, few assets are available to repay creditors holding sovereign debt: nearly all of the debtor country's assets are within its borders and presumably protected from creditors by domestic law, leaving only those assets held abroad that are not subject to sovereign immunity to repay creditors. This tends to make default less costly for debtor countries than for debtor corporations. On the other hand, when a debtor country defaults on sovereign debt owed to other countries, the default is equivalent under international law to violating an international treaty. Thus the country presumably incurs a stigma greater than that of a private corporation that files for bankruptcy. Third, compared with corporate debt, most sovereign debt has a very simple credit structure: nearly all loans are unsecured, and all have equal priority if default occurs. ${ }^{21}$ The exception is that loans from the IMF and World Bank are treated as having priority over other debt.

One can compare how lenders perceive the risk of default by corporations versus that by countries. The spread between risky and risk-free debt measures the expected value of losses due to default. The spread between interest rates on bonds rated Baa by Moody's and those on thirty-year U.S. government bonds, given in the left-hand column of table 1 for the 1990s, measures the expected cost of default by medium-risk U.S. corporations. This spread averaged 139 basis points over the decade. The righthand column gives the spread between interest rates on emerging-market debt issued in dollars or in pounds sterling and those on risk-free bonds that have the same term and are issued in the same currency. This spread averaged 261 basis points during the same period. This means that investors treated emerging-market bonds as 88 percent more risky than medium-quality U.S. corporate bonds. ${ }^{22}$

capital for investment. Table 1 of his paper shows that capital formation as a percentage of GDP during the 1980s was substantially lower in countries that had debt-servicing problems than in those that did not.

21. Eichengreen and Portes (1995) discuss the history and reasons why sovereign debt is unsecured.

22. Data on emerging-market bond spreads are taken from Eichengreen and Mody (2000, table 1). Data for U.S. corporate bond spreads and U.S. government bond yields are taken from the Board of Governors of the Federal Reserve System. Note that emergingmarket bonds are a mixture of sovereign bonds and other types of issues, some of which have explicit or implicit sovereign guarantees. 
Table 1. Yield Spreads for Medium-Quality U.S. Corporate Bonds and Emerging-Market Bonds, 1991-98

Basis points

\begin{tabular}{|c|c|c|}
\hline \multirow[b]{2}{*}{ Year } & \multicolumn{2}{|c|}{ Yield spread over risk-free bonds } \\
\hline & Baa-rated bonds ${ }^{\mathrm{a}}$ & Emerging-market bonds \\
\hline 1991 & 166 & 274 \\
\hline 1992 & 131 & 343 \\
\hline 1993 & 134 & 321 \\
\hline 1994 & 126 & 218 \\
\hline 1995 & 132 & 209 \\
\hline 1996 & 134 & 228 \\
\hline 1997 & 126 & 234 \\
\hline 1998 & 164 & 390 \\
\hline Average & 139 & 261 \\
\hline
\end{tabular}

Sources: Author's calculations based on data from Board of Governors of the Federal Reserve, and Eichengreen and Mody (2000).

a. Moody's Baa-rated long-term corporate bonds over thirty-year constant-maturity U.S. Treasury bonds.

b. Selected emerging-market bonds over risk-free bonds of comparable currency and maturity.

On the other hand, sovereign debt payoff rates following default are similar to those for companies in Chapter 11. Of three studies of Chapter 11 reorganizations of large U.S. corporations during the 1980s, two found average payoff rates to unsecured creditors of about 50 cents on the dollar, and the third found an average payoff rate of 69 cents on the dollar. In contrast, the average secondary market price for bonds of fifteen highly indebted countries in 1986-88 was 53 cents on the dollar. ${ }^{23}$ Thus the difference between the spreads on corporate bonds and those on emerging-market debt appears to be due entirely to differences in the probability of default, since the payoff rates conditional on default are similar. How debtor countries' default rates compare with the risk premium on emerging-market debt is a question for future research.

\section{Current Procedures for Dealing with Sovereign Default}

Sovereign debt is divided into four types: loans owed to the international financial institutions (IFIs; mainly the IMF and the World Bank),

23. These are noncomparable in the sense that the sovereign debt price depends on both the probability of default and the amount repaid conditional on default, whereas the corporate bond payoff is conditional on default only. But the probability of default is close to 1 for these countries. See White (1996a) and Bulow and Rogoff (1988, table 2, p. 680). 
official loans owed to governmental creditors, private loans owed to banks, and private loans owed to bondholders. ${ }^{24}$ By law, all four types have equal priority in a default, but loans from the IFIs are treated as having higher priority and are generally not rescheduled. The Paris Club is the forum for renegotiating official debt, and the London Club is the forum for renegotiating commercial bank debt. Paris Club debts are renegotiated first. For a country to be eligible for a Paris Club rescheduling, two conditions must be met. First, the IMF must certify that the country is unable to meet its debt service obligations, and, second, the country must conclude an agreement with the IMF specifying policy changes that it will adopt to avoid a repetition of its financial problems. In their negotiations, sovereign creditors insist on the principle of equitable burden sharing for both official and private creditors. This is to prevent defaulting countries from repaying a low fraction of official creditors' claims and later agreeing to repay a higher fraction of commercial creditors' claims. Traditional rescheduling terms involve a grace period of five years and then repayment over the next five years, but more concessionary terms have become increasingly common since the late 1980s, particularly for the poorest countries. ${ }^{25}$ Paris Club agreements require unanimous consent of the official creditors, but holdouts are not a serious problem, because the creditors are always the same group of large industrial countries and are experienced in this type of negotiation. Barry Eichengreen and Richard Portes cite the negotiations over Polish debt in 1990-91, which went on for fifteen months, as an instance of unusually drawn-out negotiations. ${ }^{26}$ The IMF waits to disburse new funds to the country until the Paris Club agreement has been reached.

The IMF's role in the Paris Club has no parallel under Chapter 11 and is likely to reduce moral hazard problems. Countries that are financially able to repay their debts are less likely to default, because of the need for IMF certification that the country is unable to pay its debts (although the IMF cannot prevent countries from becoming financially unable to repay their debts because of corruption or bad economic policies). Also, the agreement with the IMF concerning policy changes functions like a reor-

24. Sovereign debt crises may also involve debt owed by a country to domestic creditors and nonsovereign debt owed to international creditors. Whether and how these types of debt should be included in restructuring procedures are open questions.

25. Vitale (1995, pp. 123-26).

26. Eichengreen and Portes (1995). 
ganization plan in terms of improving the country's financial condition and increasing the probability that it will be able to meet its rescheduled debt obligations.

The London Club meets after the Paris Club has completed its work. The main creditors participating are commercial banks. A steering committee is formed, usually composed of the fifteen banks holding the largest claims. London Club agreements include a nondiscrimination clause requiring that the debtor not give more favorable treatment to dissident creditors than to members of the club. In addition, loan agreements with the commercial banks contain a clause requiring that any creditor that does receive disproportionately favorable treatment share the proceeds with other commercial creditors. Another constraint on the negotiations is that the Paris Club's requirement of equitable burden sharing prevents the debtor country from giving the commercial bank creditors more favorable treatment than the official creditors. Thus the combination of the equitable burden-sharing principle and the nondiscrimination clause requires that, in theory, all London Club creditors be treated alike and no better than Paris Club creditors. But, in practice, London Club creditors probably receive larger payoffs, because Paris Club creditors often offer easy repayment terms or debt forgiveness for political, environmental, or eleemosynary reasons. ${ }^{27}$

The London Club does not require unanimous consent of all creditors, but agreements normally involve the consent of holders of 90 to 95 percent of the outstanding debt. Because of this near-unanimity requirement and the fact that many more creditors are involved in London Club than in Paris Club negotiations, London Club negotiations tend to be slow. The London Club negotiations for Poland that started in 1981 took nearly fourteen years. ${ }^{28}$ Until 1988 the IMF would not disburse its own funds to a debtor country until a London Club agreement had been reached, but then it reversed that policy. Defaulting countries are now able to obtain IMF disbursements and other multilateral funds even though they have

27. For example, Honduras and Nicaragua were allowed to defer all debt service payments for three years following Hurricane Mitch in 1998.

28. Typical terms in a London Club rescheduling also involve a grace period, followed by repayment of principal over a set number of years at an agreed-on interest rate. The banks lend the amount of interest that would otherwise be due during the grace period. Because the principal remains the same, banks do not have to classify the loans as nonperforming. 
not concluded negotiations with the London Club. This change clearly shifted bargaining power in debtor countries' favor. ${ }^{29}$

Sachs gives several explanations for why London Club negotiations during the 1980 s were protracted. ${ }^{30}$ First, for large banks, agreeing to reduce their claims against one country in default sets a precedent for similarly favorable treatment of other countries in default. These banks therefore have an incentive to take a tough stance in negotiations for reputational purposes. Second, in the 1980s, small banks often sold their sovereign claims at a large discount, which reduced the defaulting country's cost of repaying more to the large banks. Similarly, the official creditors often offer favorable repayment terms to defaulting countries, which also increases defaulting countries' ability to repay the large banks. Thus, waiting to be the last creditor to settle with the debtor is often a profitable strategy for creditors if they can afford to wait. But, as discussed above, delay is costly to the debtor. Because of their need for new loans, defaulting countries often make agreements with commercial bank creditors that are very harsh. ${ }^{31}$

The last group of sovereign creditors, private bondholders, has become extremely important. Following the Latin American defaults of the 1980s, commercial banks' sovereign loans were rescheduled and converted into bonds — called Brady bonds — which were sold to private investors. Brady bonds caused secondary markets for sovereign bonds to develop, and as of the mid-1990s the number of such bonds had grown to the point where they constituted two-thirds of emerging-market debt. ${ }^{32}$

Most sovereign bonds are issued either in the United Kingdom under U.K. law or in the United States under U.S. law. Bonds issued under U.K. law contain collective action clauses (CACs), which permit a supermajority of bondholders - usually 75 percent_-voting at a bondholders' meeting to adopt changes in the terms of the bonds. These changes can include changes in payment terms. The changes are then binding on all bondholders. Bonds containing CACs lend themselves to restructuring, because a

29. See Eichengreen and Portes (1995, p. 28).

30. Sachs (1989).

31. Sachs (1989) argues that several of the agreements made by countries in default with their private creditors during the 1980 s were so harsh that the countries defaulted again a short time later.

32. See Eichengreen and Mody (2000). The pool of international capital flowing to emerging markets increased from \$188 billion in 1984-90 to more than \$1 trillion in 1991-97 but has fallen since then. See Blustein (2001, p. 17). 
minority of holdouts can be forced to accept changes in bond terms. In contrast, U.S.-issued bonds do not allow their payment terms to be changed except by unanimous consent. Some sovereign bonds issued in the United States do incorporate CACs that allow a majority or a supermajority of bondholders to change the terms of the bond, as long as the changes do not involve the terms of payment. ${ }^{33}$ The lack of a collective action procedure for payment terms makes rescheduling U.S.-issued bonds more difficult than rescheduling those issued in the United Kingdom.

U.S.- and U.K.-issued bonds also differ as to whether individual creditors can sue the debtor country following default. In order for litigation against the debtor to be worthwhile, creditors must be able to accelerate payments following a default, so that they can sue for the full amount of principal and interest owed in the future, rather than just for the missed interest payments. Most U.S.-issued bonds give individual bondholders the right to accelerate payment following a default. Others require that at least 25 percent of bondholders agree on an acceleration. In contrast, U.K.-issued bonds allow only the bond trustee to accelerate payment and sue the debtor country, and they require that any recovery be shared pro rata among the bondholders. ${ }^{34}$ As a result, holders of U.S.-issued bonds have an incentive to individually sue the defaulting country for repayment, whereas holders of U.K.-issued bonds do not.

A recent example of a "rogue" creditor who successfully sued a sovereign debtor illustrates the potential of creditors who hold U.S.-issued sovereign bonds to disrupt sovereign debt restructurings. Elliott Associates, a private investment firm, purchased $\$ 20$ million worth of U.S.-issued commercial loans that were guaranteed by the Peruvian government. When Peru later tried to restructure its debt, Elliott Associates sued Peru in U.S. courts for repayment. It obtained a judgment and an attachment order against Peruvian funds in the United States and Europe that were intended to pay interest on Peru's restructured Brady bonds. Peru then settled the case, paying Elliott Associates \$56 million. ${ }^{35}$ The fact that Elliott Associates was so successful will probably encourage others to follow in its

33. See Buchheit, Gulati, and Mody (2002) for an explanation and history of the U.S. practice of not allowing bond payment terms to be changed by a supermajority vote of bondholders.

34. Buchheit, Gulati, and Mody (2002).

35. Krueger (2001a). 
footsteps and is part of the IMF's justification for proposing a sovereign bankruptcy procedure.

Debtor countries choose whether to issue their bonds in the United States or the United Kingdom. Eichengreen and Mody found that 44 percent of emerging-market bonds were issued in the United Kingdom, 32 percent in the United States, and the remainder in other countries, mainly Japan and Germany. ${ }^{36}$ Because sovereign debt restructuring is easier when bonds contain CACs, a question that arises is, Why don't countries issue their debt in the United Kingdom more often? One reason is that, ex ante, borrowers do not want to draw lenders' attention to the possibility of default. On the contrary, they would like to credibly precommit not to default, and they can do so by choosing to issue in the United States, where any restructuring will be more difficult. ${ }^{37}$ Another reason is that interest rates on emerging-market bonds are generally higher in the United Kingdom than in the United States, so that issuers probably expect to pay more if they choose to issue in the United Kingdom. However, a recent study by Barry Eichengreen and Ashoka Mody found that countries with high credit ratings paid lower interest rates when they issued their debt in the United Kingdom, whereas the opposite held for countries with low credit ratings..$^{38}$ Thus creditors apparently rewarded the precommitment not to default when it was made by (mainly Latin American) countries that were viewed as likely to default, while rewarding the decision to opt for more orderly renegotiation procedures on the part of (mainly Asian) countries that were viewed as not likely to default. Finally, based on their experience up to the Argentinean default of 2002, most sovereign debtors probably expected the IMF to bail them out if they ran into trouble repaying their debt, so that no restructuring would be required in any case.

This discussion suggests that growth in the number of sovereign bonds has made the restructuring of sovereign debt increasingly difficult. Rather than the clubby discussions among bankers and diplomats at the Paris and London Clubs, restructuring now involves obtaining the unanimous consent of bondholders who lack even a forum for negotiations. Indeed,

36. Eichengreen and Mody (2000).

37. See Povel (1999) for a discussion and models of the precommitment problem.

38. Eichengreen and Mody (2000). 
because many sovereign bonds are bearer bonds, bondholders are often anonymous and impossible to contact. The fact that sovereign debt restructuring has become so difficult has put increased pressure on the IMF to bail out countries in financial distress. This in turn has led it to propose reforms that would make the restructuring process quicker and more orderly.

\section{Proposals for Reform: Bankruptcy versus Nonbankruptcy Approaches}

Two recent proposals for reform of current arrangements for distressed sovereign debtors-by the IMF and by the U.S. Treasury-adopt very different approaches to the problem.

\section{The IMF's Sovereign Bankruptcy Proposal}

In speeches during the fall of 2001, Anne Krueger, first deputy managing director of the IMF, proposed the adoption of a sovereign bankruptcy procedure..$^{39}$ Her proposal adopts many of the characteristics of Chapters 11 and 9. First, when countries file for bankruptcy, there would be an automatic stay on litigation to discourage grab races and prevent rogue creditors from disrupting the restructuring process by suing the debtor country in U.S. courts. Second, priority would be given to new, postbankruptcy private loans. This would make it easier for distressed countries to obtain new loans and reduce the cost to the IMF of funding bailouts. Third, there would be a procedure for adoption of a restructuring plan that would bind both minority creditors within a class of creditors and entire classes of creditors. As in Chapter 9, public officials would remain in charge during the procedure. However, the proposed sovereign bankruptcy procedure would differ from Chapters 9 and 11 in that the IMF would have a large role, much as it now has in sovereign debt restructurings. Debtor countries would have to get the IMF's permission to enter the sovereign bankruptcy procedure, the IMF would give countries permission to remain in bankruptcy after the initial ninety-day period, the

39. Krueger (2001a, 2001b). Krueger's speeches do not provide much in the way of specifics, however. Several other authors have made sovereign bankruptcy proposals: see Sachs (1999), Schwarcz (2000), Chun (1996), and Macmillan (1995). 
IMF would oversee the country to ensure that it does not misbehave while the restructuring procedure takes place, and the IMF would provide creditors with an assessment of whether the proposed restructuring reduces the country's debt burden to a sustainable level. The IMF would also provide new loans to the country. ${ }^{40}$

A problem with the IMF's or any other sovereign bankruptcy proposal is that it would be difficult to implement. No existing court has jurisdiction over disputes between a sovereign state and another country's citizens (in this case the bondholders). This means that no international court exists whose functions could be expanded to include adjudicating a sovereign bankruptcy. ${ }^{41}$ As discussed above, sovereign bond contracts always specify that a particular country's laws, usually the laws of the United States or the United Kingdom, govern if disputes occur. In theory this might mean that creditors could initiate an involuntary bankruptcy filing in the United States or the United Kingdom for a country that has defaulted on its debts. But U.S. bankruptcy law does not allow bankruptcy filings by sovereign states.

Two different routes to adoption of a sovereign bankruptcy procedure have been proposed. ${ }^{42}$ One involves an international treaty that would set up a sovereign bankruptcy court and would require that private creditors of a country in bankruptcy use that court rather than their own countries' courts when disputes occur. The other involves amending Article VIII of the IMF Articles of Agreement. Article VIII(2)(b) provides that

\footnotetext{
Exchange contracts which involve the currency of any member and which are contrary to the exchange control regulations of that member maintained or imposed consistently with this Agreement shall be unenforceable in the territories of any member. In addition, members may by mutual accord cooperate in measures for the purposes of making the exchange control regulations of either member more effective, provided that such measures and regulations are consistent with this Agreement.
}

Under this approach, the term "exchange contracts" would be broadened to include all contracts. Then, if a member state suspended repayment of its foreign debt with the IMF's approval, the contract would be

40. In a speech made on April 1, 2002, just before this conference, Krueger (2002) changed the IMF's proposal to reduce its own role in the restructuring process. This paper discusses only the original proposal.

41. The International Court of Justice in The Hague deals only with disputes between countries, not between a country and private citizens in another country.

42. See Greenwood and Mercer (1995) and Krueger (2001b). 
unenforceable in any IMF member country's courts. To amend Article VIII would require that three-fifths of the IMF's member countries, holding 85 percent of the IMF's voting power, approve the change. Thus both routes to adoption of sovereign bankruptcy would be difficult, because both would require legal changes by a large number of countries.

\section{Contractual Approaches to Sovereign Default}

Alternative proposals for reform of sovereign debt restructuring procedures generally involve changing the form of sovereign debt contracts, but not adopting a sovereign bankruptcy procedure. These are referred to as contractual approaches. A recent speech by John Taylor, under secretary of the U.S. Treasury for international affairs, illustrates the contractual approach. ${ }^{43}$ His proposal calls for CACs to be incorporated into all emerging-market bonds, so that a dissenting minority of creditors within any bond issue could be compelled to agree to a restructuring plan. ${ }^{44}$ All bond issues would also contain clauses specifying who would represent bondholders in restructuring negotiations with the debtor and that only the bondholders' representative could initiate litigation against the debtor. Finally, clauses in all bonds would specify that the sovereign debtor could initiate a suspension of debt payments for a fixed period prior to the start of restructuring negotiations. None of these reforms would require statutory changes. However, the IFIs have been advocating similar changes for the past several years with little effect, suggesting that carrots or sticks would be needed to induce sovereign debtors to make the changes. Along these lines, Taylor proposes that the IMF require any country that has an IMF program to incorporate these clauses into all its sovereign bond issues or, alternatively, that the IMF reward countries that cooperate by charging them a lower interest rate on their IMF borrowing. ${ }^{45}$

43. Taylor (2002).

44. The United Kingdom and Canada include CACs in their own sovereign debt, but Taylor, in response to a question after his speech, indicated that the United States has no plans to include CACs in U.S. government debt.

45. Others who have argued in favor of CACs and other contractual changes, but against adoption of a sovereign bankruptcy procedure, include Eichengreen and Portes (1995), Eichengreen and Ruehl (2000), Buchheit, Gulati, and Mody (2002), and Bartholomew, Liuzzi, and Stern (2002). Also see Nouriel Roubini's discussion paper in this symposium. 


\section{How Bankruptcy Could Improve Procedures for Sovereign Restructuring}

How could a sovereign bankruptcy procedure make the sovereign debt restructuring process more orderly? Would such a procedure increase or decrease economic efficiency? Could the same goals be accomplished using the contractual approach instead?

\section{The Moral Hazard Trade-Off}

As discussed above, a debtor's decision to default involves two types of moral hazard, and adoption of a sovereign bankruptcy procedure changes the trade-off between them. If default is very hard on firm managers or public officials, they have a strong incentive to avoid it. In their efforts to avoid default, managers may use the firm's assets for very risky projects, and public officials may raise domestic interest rates to very high levels and cause a severe recession. On the other hand, if managers or public officials are treated more favorably following a default, they may engage in opportunistic behavior that makes default more likely, such as using sovereign loans for wasteful purposes. Instituting a sovereign bankruptcy procedure would move the trade-off away from inefficient behavior to avoid default and toward too many defaults. Whether this would increase or decrease economic efficiency is difficult to judge. But if the sovereign bankruptcy procedure requires that the IMF give the country permission to default and enter the bankruptcy procedure, any reduction in economic efficiency due to additional default seems likely to be small.

\section{Controlling Grab Races and Rogue Creditors}

A central feature of all forms of bankruptcy is the automatic stay on litigation that takes effect as soon as the debtor files. The stay both discourages prebankruptcy grab races by creditors and prevents individual creditors from suing the debtor for full repayment after the bankruptcy filing. Closing off creditors' ability to litigate makes it more likely that restructuring negotiations will be successful, because it reduces creditors' opportunity cost of accepting a restructuring offer. 


\section{Postbankruptcy Financing}

Debtors in bankruptcy are allowed, with the bankruptcy judge's permission, to obtain new loans by giving the new lender's loans priority over all prebankruptcy loans. These debtor-in-possession loans are relatively easy to arrange in the context of bankruptcy (even Enron obtained one), because there is a clear legal division between loans made before and those made after the bankruptcy filing. To the extent that keeping credit flowing to sovereign borrowers even when they default reduces the negative effect of default on the debtor country's economy and population, this change would be efficiency enhancing.

\section{Preventing Creditors from Delaying and Preventing Holdouts}

A bankruptcy procedure that follows the outlines of Chapter 11 would give the debtor a number of advantages in the bargaining process over a restructuring or reorganization plan. First, the debtor would have the power to compel all creditors to come to the bargaining table at the same time. In Chapter 11, managers propose the reorganization plan, following consultation or negotiations with committees that represent different classes of creditors. All creditors then must vote on the plan. This means that all classes of creditors must either participate in the bargaining process or risk being compelled to accept a plan that emerges without their participation. Individual creditors or classes of creditors do not have the option of delaying negotiations in hopes of obtaining a better agreement with the debtor after other creditors have settled, because the plan, if adopted, would resolve their claims. Second, managers have the right to propose at least the initial plan, whereas creditors can only accept or reject it. The right to make an offer rather than have to accept or reject another's offer allows managers to capture additional surplus. ${ }^{46}$ These provisions, if applied to a sovereign bankruptcy procedure, would give debtors greater bargaining power vis-à-vis creditors than they have outside of bankruptcy.

Chapter 11 also incorporates provisions for overriding both dissenting minorities within creditor classes and entire dissenting classes. As dis-

46. See Bebchuk and Chang (1992) for a model of the Chapter 11 bargaining process. 
cussed above, the voting procedure for a reorganization plan allows a strong majority of each class of creditors to compel a dissenting minority within any class to agree to the plan. Thus the voting procedure for a reorganization plan in bankruptcy in effect incorporates CACs into each bond issue, regardless of whether the original bond issue contained them or not. In addition, if some classes of creditors reject the plan, the bankruptcy judge can override the dissenting classes and adopt the plan anyway using cramdown. The cramdown procedure used in Chapter 11 reorganization allows a plan to be adopted even if only one class of creditors votes in favor of it by the required supermajority. If a similar form of cramdown were incorporated into a sovereign bankruptcy procedure, it would go far beyond CACs in giving the debtor power to compel holdouts to agree to a plan.

As discussed above, cramdown is only one alternative procedure that could be used to compel dissenting classes of creditors to agree to a restructuring plan. Another possibility is for the bankruptcy judge to order a sovereign liquidation under a procedure like Chapter 7. Because the payoff to creditors in a sovereign liquidation would be very low, the prospect of liquidation would serve as a penalty to be levied on all creditors for failing to agree on a restructuring plan. It would give them a strong incentive both to participate in restructuring negotiations and to moderate their demands. But a sovereign liquidation, if it occurred, could also penalize debtors. The loss to a country of its external assets would be costly even if their value were low, and credit markets might punish sovereign debtors more for a sovereign debt liquidation than for a sovereign debt restructuring.

Thus a sovereign bankruptcy procedure-if it followed the outlines of Chapter 11-would increase the debtor country's bargaining power with respect to its creditors by forcing all creditors to negotiate simultaneously, to accept or reject the debtor's offer, and to accept a restructuring plan even when they would prefer to hold out. Not surprisingly, creditors are against the adoption of sovereign bankruptcy, because they feel that they are better off under the status quo. ${ }^{47}$ Whether sovereign lending by private bondholders would survive the adoption of a sovereign bankruptcy procedure is an open question.

47. Paul Blustein, "IMF Crisis Plan Torpedoed: Treasury Official Rejects Proposal a Day after It Is Advanced," Washington Post, April 3, 2002, p. E1. 


\section{Simpler Approaches to Improving Procedures for Sovereign Debt Restructuring}

Could reforms that stop short of a sovereign bankruptcy procedure improve the process of sovereign debt restructuring? If so, how? Most of the discussion here concerns contractual rather than statutory changes, such as widespread use of CACs in sovereign debt. But statutory reforms that involve changing only the laws of the United States or the United Kingdom or other money center countries are also considered.

\section{Preventing Litigation by Individual Creditors}

The problem of individual creditors acting as holdouts in the restructuring process and suing the debtor for full repayment could be addressed in simpler ways than creating a sovereign bankruptcy procedure. As discussed above, sovereign bonds issued under the laws of the United Kingdom generally contain clauses that prevent individual creditors from accelerating their claims and suing the debtor following default. If all sovereign debtors included these clauses in all of their debt issues, as in Taylor's proposal, ${ }^{48}$ individual creditors would be barred from suing the debtor both before and after default. However, this approach would not prevent a trustee who represented a majority of holders of a particular bond issue from suing the debtor. In addition, because many long-term sovereign bonds were issued in the United States and do not contain CACs, this solution could have a long transition period.

A recently developed contractual technique for dealing with bonds that do not contain CACs is exchange offers combined with exit consents. ${ }^{49}$ Many U.S. bonds allow 25 percent or more of the holders of a bond issue to agree on an acceleration of claims, but they also allow a simple majority of creditors to rescind any previously agreed-on acceleration. If creditors have accelerated their claims or if the sovereign debtor fears that they might, the debtor can offer bondholders a voluntary exchange of new bonds for old, combined with a set of amendments to the terms of the old bonds, referred to as exit consents. Bondholders who accept the exchange offer automatically vote for the amendments, which become binding as long as the required majority or supermajority of old

48. Taylor (2002).

49. See Buchheit and Gulati (2000); Buchheit, Gulati, and Mody (2002). 
bondholders accepts the exchange. The amendments are intended to poison the old bonds, both by rescinding any previously agreed-on acceleration of payments and by changing other nonpayment terms to make the old bonds less valuable. As an example, an amendment might drop the requirement that the bond issue be publicly listed, so that the old bonds become unmarketable. By making the terms of the old bonds worse, the exit consents give bondholders an incentive to accept the exchange. A standard prisoners' dilemma argument suggests that individual bondholders have an incentive to accept the exchange as long as they expect other bondholders to accept, even if accepting it makes them worse off. The reason is that if they do not accept and the exchange succeeds anyway, they will be even worse off.

But exchange offers and exit consents may not be as effective as their advocates argue. If bondholders are difficult to reach because bonds are in bearer form or if a large majority must accept the exchange, an exchange offer may fail. In fact, when Ecuador used an exchange offer in 2000 to modify the terms of its U.S.-issued bonds, it offered substantial financial enhancements to those who accepted, including cash payment of accrued but unpaid interest and a shorter term to maturity. ${ }^{50}$ Whether the exchange would have succeeded without these sweeteners is unclear, since the technique is new. Thus, contractual approaches to preventing litigation may either fail or succeed but be very costly to the debtor.

An alternative approach would be for the United States and the United Kingdom to change their laws governing sovereign immunity. Both countries adopted legislation in the 1970s that narrowed their definitions of sovereign immunity to exclude sovereigns' commercial assets. ${ }^{51}$ If this legislation were reversed, creditors would have nothing to gain from pursuing litigation against sovereign debtors-either individually or as a class. ${ }^{52}$ Because these changes would only involve reforming the law in the United States or the United Kingdom, they would be much simpler to implement than a sovereign bankruptcy procedure.

Finally, an even simpler solution would be for sovereign debtors to avoid holding assets in the United States or the United Kingdom. Sover-

50. A similar exchange offer by Pakistan also included financial incentives. See IMF (2001), boxes 2.2 and 2.4 , pp. 5 and $7-8$.

51. The U.S. Foreign Sovereign Immunities Act was adopted in 1976, and the U.K. State Immunity Act in 1978. See Kaletsky (1985, p. 22).

52. This has been suggested by Bulow and Rogoff (1989) and Rogoff (1999). 
eign bank accounts could simply be shifted to countries that adhere to a broad definition of sovereign immunity.

\section{Preventing Holdouts by Using CACs}

If all bond issues had CACs, sovereign debtors would have the power to prevent a minority of creditors within each bond issue from acting as holdouts, as long as the required supermajority within each bond issue was willing to accept a restructuring plan. However, even with CACs, bondholders cannot be forced to accept a restructuring offer if the group of bondholders that prefers to hold out is larger than the number required to block agreement (usually one-fourth in U.K.-issued sovereign bonds). Similarly, even if all bond issues contained CACs, bondholders could not be forced to come to the bargaining table if the group of bondholders that prefers to delay negotiations is larger than the blocking minority. Thus CACs by themselves do not prevent holdouts and do not give the debtor the power to force all bondholders to participate in negotiations, if the dissenting minority is large enough.

An additional problem with CACs is that individual bondholders can easily defeat them by purchasing at least a blocking minority of any particular bond issue. In the future, creditors may demand that debtors provide many smaller bond issues, or may demand that the blocking majority be reduced in size, so that investors can count on controlling any bond issue they purchase. ${ }^{53}$ Another problem is that if more bond issues in the future contain CACs, creditors' gain from holding bond issues that do not contain CACs will rise. Being a holdout becomes more profitable the fewer the number of other potential holdouts, because the sovereign debtor is more likely to buy out holdouts when they are few. Thus creditors may defeat attempts to make CACs universal by offering better terms on sovereign bond issues that do not contain them or by buying only small issues in which they can purchase a majority. ${ }^{54}$ In effect, the market may defeat attempts to make CACs universal.

53. However, if bond issues are too small, they become unmarketable.

54. See Bartholomew, Liuzzi, and Stern (2002) for a proposal that sovereign debtors begin a restructuring by making an exchange offer that would consolidate all of the sovereign debtor's existing bond issues into a single set of new bond issues. Exit consents would be used to poison all of the old bond issues. But even this proposal, which would be costly to the debtor, would not deal with bond issues in which a holdout debtor controlled a blocking minority. 
As discussed in the previous section, exchange offers can also deal with bond issues in which CACs are ineffective because the group of dissenters is too large. But, again, exchange offers are likely to be very costly to the debtor.

\section{Debtor-in-Possession Financing without Bankruptcy}

Finally, can contractual reforms make it possible for sovereign debtors to obtain new loans when default is likely or has already occurred (that is, debtor-in-possession financing without bankruptcy)? The new creditor would presumably require that its loan take priority over all the debtor's previous loans, perhaps with the exception of loans from the IFIs. Such a violation of equal priority would change the terms of all prior bond issues and would require unanimous consent of all bond issues. For bond issues containing CACs, approval would require a supermajority vote of bondholders. For U.S.-issued bonds, the same type of approval would be needed, since this change does not alter the terms of payment of the bond. Thus a majority or supermajority of each bond issue would have to consent. Presumably most bond issues would consent, particularly if the IMF also offered new financing on condition of priority for the new private loan. However, at least some bond issues are likely to act as holdouts and not agree to the change, because suing the debtor for full repayment would be more financially attractive after the country received the new loans. But without unanimous consent of all prior bond issues, the priority status of the new loan would be in doubt, and thus private new loans would not likely be available. Overall, it seems unlikely that contractual changes short of adopting a sovereign bankruptcy procedure would be sufficient to allow sovereign debtors to obtain new private loans once default has become likely or has already occurred. CACs cannot substitute for bankruptcy along this dimension.

\section{Fairness}

A final issue is how CACs or a sovereign bankruptcy procedure would affect the fairness of payoffs to creditors following default. In other words, do all creditors take an equal haircut because they have equal priority? Under a contractual system involving CACs, creditors' returns across bond issues are likely to vary considerably, depending on whether individual creditors have majority control of their bond issues and 
whether exchange offers are required to obtain their consent to a restructuring plan. In contrast, under a sovereign bankruptcy procedure, debtors would have greater bargaining power and could probably compel bond issues to agree to haircuts that are more uniform.

\section{Conclusion}

Do sovereign states in financial distress need a sovereign bankruptcy procedure to accomplish an orderly restructuring, that is, to prevent individual lawsuits against the debtor, compel dissenting minority and majority groups of creditors to negotiate over and accept a restructuring plan, and allow the sovereign debtor to obtain new private loans following default? I have argued that contractual changes short of bankruptcy, such as incorporating CACs in sovereign bond issues, are unlikely to accomplish these goals. Although CACs allow the debtor to compel a minority of holders of any bond issue to accept changes in the terms of their bonds, they do not allow the debtor to override holdout groups that are larger than a blocking minority of any particular bond issue. Exchange offers can overcome this problem for individual bond issues but are likely to have a very high cost. However, a sovereign bankruptcy procedure could accomplish all three goals at relatively low cost to the debtor country.

Thus adoption of a sovereign bankruptcy procedure would improve efficiency by reducing the high costs of default to sovereign debtors' economies and their citizens' welfare. But such a procedure could be overkill in that it might dry up the sovereign bond market completely. 


\section{References}

Bartholomew, Ed, Angela Liuzzi, and Ernest Stern. 2002. “Two-Step Sovereign Debt Restructuring: A Market-Based Approach in a World without International Bankruptcy Law.” New York: J.P. Morgan Chase \& Co.

Bebchuk, Lucien Ayre, and Howard F. Chang. 1992. "Bargaining and the Division of Value in Corporate Reorganization." Journal of Law, Economics, and Organization 8(2): 253-79.

Berglof, Erik, and Ernst L. von Thadden. 1994. "Short-Term versus Long-Term Interests: Capital Structure with Multiple Investors." Quarterly Journal of Economics 109(4): 1055-84.

Blustein, Paul. 2001. The Chastening: Inside the Crisis That Rocked the Global Financial System and Humbled the IMF. New York: PublicAffairs.

Buchheit, Lee C., and G. Mitu Gulati. 2000. "Exit Consents in Sovereign Bond Exchanges." UCLA Law Review 48(October): 59-84.

Buchheit, Lee C., G. Mitu Gulati, and Ashoka Mody. 2002. "Sovereign Bonds and the Collective Will." Working Paper 34. Georgetown-Sloan Project on Business Institutions, Georgetown University Law Center, Washington.

Bulow, Jeremy I., and Kenneth Rogoff. 1988. "The Buyback Boondoggle." BPEA 2:1988, 675-98.

- 1989. "Sovereign Debt: Is to Forgive to Forget?" American Economic Review 79(1): 43-50.

Bulow, Jeremy I., and John B. Shoven. 1978. "The Bankruptcy Decision.” Bell Journal of Economics 9(2): 437-56.

Chun, John H. 1996. “'Post-Modern' Sovereign Debt Crisis: Did Mexico Need an International Bankruptcy Forum?” Fordham Law Review 64(May): 2647-77.

Eaton, Jonathan, and Raquel Fernandez. 1995. "Sovereign Debt.” In Handbook of International Economics, vol. 3, edited by Gene M. Grossman and Kenneth Rogoff. Elsevier Press.

Eaton, Jonathan, and Mark Gersovitz. 1981. "Debt with Potential Repudiation: Theoretical and Empirical Analysis." Review of Economic Studies 48(2): 289-309.

Eichengreen, Barry, and Ashoka Mody. 2000. "Would Collective Action Clauses Raise Borrowing Costs?” Working Paper 7458. Cambridge, Mass.: National Bureau of Economic Research (January).

Eichengreen, Barry, and Richard Portes. 1995. Crisis? What Crisis? Orderly Workouts for Sovereign Debtors. London: Centre for Economic Policy Research.

Eichengreen, Barry, and Christof Ruehl. 2000. "The Bail-In Problem: Systematic Goals, Ad Hoc Means.” Working Paper 7653. Cambridge, Mass.: National Bureau of Economic Research (April).

Greenwood, Christopher, and Hugh Mercer. 1995. "Considerations of International Law." In Crisis? What Crisis? Orderly Workouts for Sovereign Debtors, 
edited by Barry Eichengreen and Richard Portes. London: Centre for Economic Policy Research.

Hart, Oliver, and John Moore. 1998. "Default and Renegotiation: A Dynamic Model of Debt." Quarterly Journal of Economics 113(1): 1-41.

International Monetary Fund. 2001. Involving the Private Sector in the Resolution of Financial Crises-Restructuring International Sovereign Bonds. Washington.

Jackson, Thomas H. 1986. The Logic and Limits of Bankruptcy Law. Harvard University Press.

Kaletsky, Anatole. 1985. The Costs of Default. New York: Priority Press Publications.

Krueger, Anne. 2001a. "International Financial Architecture for 2002: A New Approach to Sovereign Debt Restructuring." Address given at the National Economists' Club, November 26. (www.imf.org/external/np/speeches/2001/ 112601.htm, accessed on May 6, 2002.)

- 2001b. "A New Approach to Sovereign Debt Restructuring." Speech given at the Indian Council for Research on International Economic Relations, Delhi, India, December 20. (www.imf.org/external/np/speeches/2001/122001. htm, accessed on May 6, 2002.)

—. 2002. "New Approaches to Sovereign Debt Restructuring: An Update on Our Thinking." Speech given at a conference on "Sovereign Debt Workouts: Hopes and Hazards," Institute for International Economics, Washington, April 1. (www.imf.org/external/np/speeches/2002/040102.htm, accessed on May 6, 2002.)

Macmillan, Rory. 1995. "Towards a Sovereign Debt Work-out System." Journal of International Law and Business 16(1): 57-106.

McConnell, Michael W., and Randal C. Picker. 1993. "When Cities Go Broke: A Conceptual Introduction to Municipal Bankruptcy." University of Chicago Law Review 60(Spring): 425-95.

Povel, Paul. 1999. “Optimal 'Soft' or 'Tough' Bankruptcy Procedures.” Journal of Law, Economics, and Organization 15(3): 659-84.

Rogoff, Kenneth. 1999. "International Institutions for Reducing Global Financial Instability." Journal of Economic Perspectives 13(4): 21-42.

Sachs, Jeffrey D. 1989. "Efficient Debt Reduction." In Dealing with the Debt Crisis, edited by Ishrat Husain and Ishac Diwan. World Bank.

- 1999. "The International Lender of Last Resort: What Are the Alternatives?" In Rethinking the International Monetary System, edited by Jane Sneddon Little and Giovanni P. Olivei. Conference Proceedings Series 43. Federal Reserve Bank of Boston (June).

Schwarcz, Steven L. 2000. "Sovereign Debt Restructuring: A Bankruptcy Reorganization Approach.” Cornell Law Review 85(101): 101-87. 
Stiglitz, Joseph E. 1972. "Some Aspects of the Pure Theory of Corporate Finance: Bankruptcies and Take-Overs." Bell Journal of Economic and Management Science 3(2): 458-82.

Taylor, John. 2002. "Sovereign Debt Restructuring: A U.S. Perspective." Paper presented at a conference on "Sovereign Debt Workouts: Hopes and Hazards," Institute for International Economics, Washington, April 2. (www.ustreas.gov/ press/releases/po2056.htm, accessed on May 6, 2002.)

Vitale, Giovanni. 1995. "Multilateral Sovereign Debt Restructuring: The Paris Club and the London Club." In Crisis? What Crisis? Orderly Workouts for Sovereign Debtors, edited by Barry Eichengreen and Richard Portes. London: Centre for Economic Policy Research.

Webb, David C. 1991. "An Economic Evaluation of Insolvency Procedures in the United Kingdom: Does the 1986 Insolvency Act Satisfy the Creditors' Bargain?" Oxford Economic Papers 43(1): 139-57.

White, Michelle J. 1989. "The Corporate Bankruptcy Decision.” Journal of Economic Perspectives 3(2): 129-52.

1996a. "Survey of Evidence on Business Bankruptcy." In Corporate Bankruptcy: Economic and Legal Perspectives, edited by Jagdeep S. Bhandari and Lawrence A. Weiss. Cambridge University Press.

. 1996b. "The Costs of Corporate Bankruptcy: A U.S.-European Comparison." In Corporate Bankruptcy: Economic and Legal Perspectives, edited by Jagdeep S. Bhandari and Lawrence A. Weiss. Cambridge University Press.

. 1998. "Corporate Bankruptcy." In The New Palgrave Dictionary of Economics and the Law, edited by Peter Newman. London: Macmillan Press. 
